\title{
County Education Bursary Fund Influence On Access To Secondary Education In Siaya County, Kenya
}

\author{
Dickens Oketch \\ Department of Education Management and Foundations, \\ Maseno University, P.O. Box Private Bag, Maseno, Kenya. \\ James Ochieng Sika Ph.D \\ Department of Education Management and Foundations, \\ Maseno University, P.O. Box Private Bag, Maseno, Kenya. \\ Julius otieno Gogo Ph.D \\ Department of Education Management and Foundations, \\ Maseno University, P.O.Box Private Bag, Maseno, Kenya.
}

\begin{abstract}
Globally, there exist bursary schemes that are in place to enhance access and equity in the provision of education to the disadvantaged. In Kenya, there have been bursary schemes that enhances access and equity in the provision of secondary school education.With Siaya County's $16 \%$ of the population having secondary school education, below the neighbouring Kisumu county's 25\%, Vihiga county's $20 \%$ and Kakamega county's 19\%, coupled with inequity in bursary distribution, the County Government of Siaya came up with Siaya County Educational Bursary Fund (SCEBF) to help improve access and equity in the acquisition of secondary school education. The purpose of the study was to examine the extent to which the bursary scheme was equitably distributed in Siaya county. Objectives of the study was establish extent to which county education bursary fund allocation to the recipient influences access to secondary education in Siaya County. Descriptive survey and correlational research designs were used in the study. A third of the principals' population which is 68 secondary school principals and 425 students sampled using Yamane's formular formed the study sample. The study results indicates that SCEBF allocation had a unique significant contribution to access to secondary education $(\beta=.564, p=.000)$. the findings further show that enrollment changed at about $31.8 \%$ due to funding allocation in the county. The study recommended that there is need to increase allocation of bursary fund to enhance access to secondary education in the county.
\end{abstract}

\section{INTRODUCTION AND BACKGROUND}

In America there was No Child Left Behind Act (NCLB) in 2001 passed by the congress. This was a re-authorization of the elementary and secondary education act of 1965 and it has since become the focal point of education policy. According to former president George W. Bush in 2004, these reforms expressed his deep belief in US public schools and character of every child, from every background in every part of America. The essence of NCLB was to widen access especially for those who have been ostracized by virtue of their socio- economic status or race.NCLB failed to provide real access to minority students' reason being poor funding.Participation of secondary education with a cost equivalent of US \$200-300 represents a heavy financial burden even for middle income families. In many countries fees and private cost often make it impossible in the absence of affectively targeted financial support for the few poor children that complete primary education to enroll in secondary school further skewing participation towards wealthy households (Lewin, 2002). 
In Burkina Faso, education was modeled after that of France, Secondary admission for long was restricted to those who passed a standard entrance examination rationing, the number was not necessary as very few completed the secondary tier.Internal efficiency of the schools was disappointing as repeaters were quite high at all tiers;dropout rate was illustrated by fewer first grade entries. High unit cost in education per student constrained resources and made education available to limited eligible children. Access to education was more available to those living in urban locations and unequally distributed between boys and girls due to poverty hence schools were internally and externally inefficient.

Maeke (2003) looked at the problem of access and school dropout in Mali and found out that the low socio economic levels of parents were among the factors that hindered access and further led to dropout among the few students who had managed to enroll in schools. A study carried out by Ayiga (1997), looked at "Causes of Low Enrollment and high dropout rates in primary education in Uganda" and found out that lack of school fees was among the major factors that hindered access to schooling.

Uganda became the first country in Sub-Saharan Africa to introduce universal secondary education in 2007 coming 10 years after it introduced universal primary education. According to the Government of Uganda (2010) at that time, a United Nations (UN) report said Africa had the worst secondary school enrolment rates in the world with only $34 \%$ of secondary schoolage learners enrolling in class. Girls and poorer young people comprised the bulk of those locked out of school by financial and cultural constraints.

Njeru and Orodho (2003) observed that the aim of the bursary scheme in secondary school had the objective of enhancing access to, and ensure high quality secondary education for all Kenyans particularly the poor and vulnerable groups as well as the girl child thus reducing the existing inequalities. The study identified major weaknesses of the secondary school bursary scheme as lack of transparency, inadequacy of funds, fluctuations of the amount allocated, disbursement delays, lack of uniform criteria for identification of the poor students and inadequateequityconsideration.

Nyakeri (2011) carried out a study on access to education but tied it with Subsidized Secondary School Education. The study specifically looked at the Effects of Subsidized Secondary School Education on Access and Participation in Manga District, Nyamira County.The study revealed that despite the introduction of Subsidized Secondary Education, many school going children remained out of school as there was decline in enrollment in Manga District after 2009. These studies looked at access but through Subsidized Secondary Education and recommended that the government should consider allocating more funds on its annual budget to put up more facilities and improve on access to secondary education. It was necessary to look for an alternative financing method of boosting secondary school education in order to promote access and SCEBF was that alternative. This study therefore, looked at access to secondary education in public schools but tied it to County Bursary Fund using Siaya County as the site for the study.

Due to the rising cost of living, many students from poor families fail to access and drop out of their secondary education. Even with the subsidized secondary education in Kenya,the operational cost has remained high with an avarage cost of boarding secondary schools at Ksh.53,553,Special school Ksh.37,210 and day secondary school at Ksh.9,374 which is to be paid in the ratio of 50:30:20 in the three terms (MoEST, 2015), locking out many students from poor backgrounds. 
Government funding programmes have made considerable contribution to transition from primary to secondary school. It is impressive that the rate has steadily increased from $45.8 \%$ in 2003 to $59.9 \%$ in 2008 and over 70\% in 2009 (Republic of Kenya, 2010),72\% in 2010 and $76.8 \%$ in 2013(MoE,2014). The greatest increment was realized between 2008 and 2010 with the introduction of tuition free secondary education in 2008, and increase in bursary allocations. The introduction of tuition free secondary education saw an increase by $15 \%$ which raised enrolment from 1,180,267 in 2007 to 1,382,211 in 2008 (Republic of Kenya, 2009). However, despite the introduction of free day secondary education and bursary allocation, access and participation at secondary level has remained proportionately low relative to primary level participation in Kenya. For instance, in 2004, enrolment at Early Childhood Education level, primary and secondary levels stood at 1,627,721 (16.4\%), 7,394,763 (74.3\%) and 926,149 (9.3\%) respectively (MoE, 2005). In 2009, the enrolment was approximately 2.2 million (16\%) at Early Childhood Education, 9.4 million (70\%) primary school and 1.8 million (13\%) secondary school (2009 Census Report). Analysis of the 2009 census data reveals that approximately 6.7 million children of school going age were out of school. Of these, 2.1 million (58\%) were of pre-primary age, 1.9 million (23\%) primary and 2.7 million (76\%) secondary school age (Government of Kenya, 2009).

With the introduction of devolved government and commencement of its' operation in 2013, there is an establishment of a fund to be known as the County Bursary Fund which shall be a county fund consisting of monies of an amount of not less than 1.5 percent of the county government budget in every financial year as it may be appropriated by the County Assembly and shall be deposited into that fund at the first quarter of every financial year. (Government of Kenya, 2010).

Several Counties have henceendeavoured to promote access and equity in the provision of secondary school education through bursaries.Vihiga county's Ksh.125 million for bursary was disbursed to its' 25 county wards each ward getting Ksh.3million benefiting 26,000 needy students in the county,(Vihiga County Records,2015) and Kisumu County disbursed Ksh 2 million equally to all the 35 county wards as bursaries in 2016 (Kisumu county Records 2016).Siaya County has $16 \%$ of the population having secondary school level of education below Kisumu county's 25\%,Kakamega county's 19\% and Vihiga county's 20\%,(KNBS,2013) hence the need to ensure improvement of access to secondary school education in the county, one such way is through educational bursaries.

Siaya county had set aside Ksh.30 million for the educational bursaries in the financial year 2013/14 that benefited 4,800 students in the county and Ksh.49.8 million benefiting 6,400 students in the county in 2014/15 financial year.In this disbursements, the funds were equaly distributed in all the thirty county wards in the county without concidering the ward's need level.There is need therefore to assess the contribution of SCEBF against one of its main objectives "to ensure access and equity in the provision of education ."(Siaya County Social Audit Report, 2014).

\section{Statement of the problem}

The introduction of free secondary education in 2008 was a blessing to many parents since the government decided to pay ksh 10,265 per year for each student, it had subsequentely been increased to Ksh 12,870 per student in 2015.Unfortunately,the subsidy did not cover boarding expenditure,uniform among others hence making secondary education unafordable to the poor families. In Siaya county where $57.9 \%$ of the population live below poverty line and only $16 \%$ of the population have secondary school education, coupled with inequity in bursary allocation, access and equity in the provision of secondary school education hence remains a 
great concern especialy among those families from poor background dispite the existence of some bursary schemes. To help improve access and equity in the provision of secondary school education, The County Government of Siaya in its annual budget continued to give bursaries to needy secondary school students. The amount given for bursaries are equaly distributed in the 30 county wards without any consideration in terms of county ward's level of need.It is on this background that a study on the contribution of county bursary fund on access and equity in financing secondary school education in Siaya county is taken. The research was guided by the following specific objectives: To determine the county education bursary fund influence on access to secondary school education in Siaya county

\section{LITERATURE REVIEW}

In America there was No Child Left Behind Act (NCLB) in 2001 passed by the congress. This was a re-authorization of the elementary and secondary education act of 1965 and it has since become the focal point of education policy. According to former president George W. Bush in 2004, these reforms expressed his deep belief in US public schools and character of every child, from every background in every part of America. The essence of NCLB was to widen access especially for those who have been ostracized by virtue of their socio- economic status or race.NCLB failed to provide real access to minority students' reasons being poor funding.

Participation of secondary education with a cost equivalent of US \$200-300, represents a heavy financial burden even for middle income families. In many countries, fees and private cost often make it impossible in the absence of effectively targeted financial support for the few poor children who complete primary education to enroll in secondary school further skewing participation towards wealthy households (Lewin, 2002).

Studies by World Bank, (2007) indicate that many World Bank client countries in Latin America and East Asia have shown an increasing interest in expanding and strengthening their secondary education systems though with many challenges. These include lower completion rates for young people from lower income levels. Lack of private resources is a key determinant of access to and completion of secondary education and their being retained in these schools. Direct costs of education represent $22 \%$ of per capital household income in Bolivia and 20-30\% in china which most households cannot afford. (World Bank, 2007). Education provides gateway for great opportunities in life that can cushion communities against the poverty trap. It grants possibilities for knowledge acquisition to improve well-being including improvement in health, use of appropriate technologies in a highly technology dependent world and sharing of entrepreneurial skills and hence should be made easily accessible to all including the disadvantaged.

The Secondary Education in Africa (SEIA) initiative conducted a participatory process of analysis, dialogue and reflection in sub- Sahara Africa with conclusion that countries need to address the triple challenge of expanding access, improving quality and ensuring equity in education (Veerspoor, 2007). SEIA also argue that governments in this region need to allocate on average nearly 6\% of Gross National Product (GNP) to secondary schools to achieve GER of $85 \%$. Education is a profitable private investment yet many students cannot afford to finance it out of their own family resource (Psacharopolous \& Woodhall, 1985).

Governments therefore need to provide funds to support a broad based equitable expansion of secondary education with incentives for private provision and subsidies to disadvantaged students to ensure equality of opportunity and eventually eradicate poverty (Veerpoor, 2007; Psacharopolous \& Woodhall, 1985). Ayot and Briggs (1992) identified various student aid 
policies including tuition- free schooling, scholarships and bursaries to needy students, student's loan and voucher specifically for education. However, studies on effects of subsidies in Colombia, Malaysia, Kenya and Indonesia all suggest that the methods need to be reappraised since they do not achieve both efficiency and equity objectives (Psacharopolous \& Woodhall, 1985).

In Burkina Faso, education is modeled after that of France. Secondary admission for long was restricted to those who passed a standard entrance examination, rationing the number was not necessary as very few completed the secondary tier. Internal efficiency of the schools was disappointing as repeaters were quite high at all tiers; dropout rate was illustrated by fewer first grade entries. High unit cost in education per students constrained resources and made education available to limited eligible children.Access to education was more available to those living in urban locations and unequally distributed between boys and girls due to poverty hence schools were internally and externally inefficient.

Maeke (2003) looked at the problem of access and school dropout in Mali and found out that the low socio economic levels of parents were among the factors that hindered access and further led to dropout among the few students who had managed to enroll in schools. A study carried out by Ayiga (1997), looked at "Causes of Low Enrollment and high dropout rates in primary education in Uganda" and found out that lack of school fees was among the major factors that hindered access to schooling.

While the past decade has seen tremendous increase in primary school access in Kenya, secondary school access remains low. In 2009, the secondary school net enrollment rate was approximately 50\% (World Bank, 2009), while the primary-to-secondary school transition rate was equally low at 55\% (MOE, 2010). Despite the recent reductions in secondary school fees, these fees still present a major financial obstacle. The 2005 Kenya Integrated Household budget shows that on average secondary school expenditures accounted for approximately $55 \%$ of annual per capita household expenditures. While the increased availability of bursaries (e.g. from the CDF) have provided many families with financial assistance, the pressing burden of secondary school fees prevent many students from attending secondary schools. These financial barriers are especially seen in the case of females and vulnerable groups such as orphans, and the poor.

Ngware, Onsomu, Muthaka and Kosimbei (2006) conducted a study to examine strategies for improving access to secondary education in Kenya. They concluded that persistently low participation rates from low income households indicates that the bursary fund has limited impact on ensuring that the beneficiaries are adequately supported for a full cycle. Consequently, they proposed that the government initiative in decentralizing and reviewing bursary funds management to constituency level should be closely monitored. Clear guidelines should be developed to ensure efficiency and effectiveness in order to increase access to secondary education. Further they suggest that there is no address to income inequalities in the society, and that a special assistance scheme and preferential policies should be developed to target vulnerable groups such as students from marginalized communities, those with special needs, orphaned and vulnerable children.

In other studies carried in Kenya on government bursary by Orodho, Njeru (2003) and Mellen (2004), the results of the studies shows that the government bursary fund is yet to achieve its main objective of ensuring access and quality education. Their studies have evaluated the students' bursary fund scheme and found out that the funds are not effective generally and are strained with defaults. Mirigat (2003) reports that "of the richest $20 \%$ households, $76 \%$ of 
their children attend school compared to $40 \%$ of the poorest $20 \%$ households. This means that children from poor households have much lower attendance. The bursary fund allocation levels to beneficiaries is therefore too low to cover the entire fees for those assessed as poor and needy, especially in boarding schools now that the government is implementing a tuition fee waiver for all students in all public schools (IPAR, 2009).

Recent studies in Kenya have looked at equity and efficiency of financing education by the government through local authorities, Kodingo (2006) and through bursary scheme, Odebero (2002). These studies have revealed that many secondary school going children from poor household are not enrolled.Therefore,other sources need to be identified to supplement these sources to improve access.According to the National Development Plan 2002-2008,Republic of Kenya (2003),one of the ways of improving secondary school access was to build more day secondary schools.

A study conducted by Kiage (2003) on impact of cost-sharing policy on secondary education enrolment in Nyamira district revealed that most of the students who leave school prematurely can be attributed to lack of school fees, this he noted accounted for up to 2.638 percent of drop out in schools. A related study conducted in Bungoma district by Wachiye (2005), on equity and access to higher education discovered that accesss to university education is largely limited to children from medium and higher income groups in the society, this raises the question on how best the children from poor families can be assisted to acquire secondary school education.

Nyakeri (2011) carried out a study on access to education but tied it with Subsidized Secondary School Education. The study specifically looked at the Effects of Subsidized Secondary School Education on Access and Participation in Manga District, Nyamira County. The objectives were to determine the enrolment of students in public day secondary schools before and after implementation of subsidized secondary school education, to identify challenges facing the implementation of Subsidized Secondary Education (SSE) and their solutions and to analyze the effects of SSE.Using the theory of Equal Opportunity and Social Darwinism, the study asserted that the orientation on equality brought about by access and participation in education is determined by the ability of learners to pay the user charges levied by the school or else they drop out of school.

The study revealed that despite the introduction of Subsidized Secondary Education, many school going children remained out of school as there was decline in enrollment in Manga District after 2009. The studieslooked at access but through Subsidized Secondary Education and government bursaries and recommended that the government should consider allocating more funds on its annual budget to put up more facilities and improve on access to secondary education. It was necessary to look for an alternative financing method of boosting secondary education in order to promote access and SCEBF was that alternative. This study therefore looked at access to secondary education in public schools but tied it to County Bursary Fund using Siaya County as the site for the study.

\section{Research Design}

\section{RESEARCH DESIGN AND METHODOLOGY}

Descriptive survey and correlational research design were adopted.Saunders,Lewis and Thornhill (2007) defines research design as a structure of research.It is the glue that holds all the elements in a research project together.It is the major type of discipline research which gives description of the state of affairs as they exist.Orodho (2003) states that descriptive 
survey is a method of collecting information by interviews or administering a questionnaire to a sample of individuals to determine research statistics of a problem and justify current situation or condition.Descriptive survey design was deemed relevant to the study because the questionnaire constructed helped the researcher to solicit for the desired information. Correlational design was also deemed suitable because it gives a measure of extent to which value on one variable can be predicted from values of on the other variable (Cohen, 1992).

\section{Sample Size and Sampling Techniques}

A total of 68 secondary school principals,that is a third of the population, (Bell, 1993) was sampled through strstified random sampling technique.The number of students sampled were 425; this sample was obtained using a formular advanced by Yamane in 1967(Israel,1992). Stratified random sampling was used to represent thirty county wards this ensured proportionate representation of the study since a proportion of schools was selected from each county ward.Schools were grouped into different types as boarding, day,mixed, boys and girls into different categories as Sub-County, County schools and also National schools to ensure fair representation of students from diverse backgrounds.County Executive Committee Member for Education andWard Administrators were determined through saturated sampling since a small population was involved.This is in line with Orodho (2005) who observed that small population can form samples and be studied as distinct cases.

\section{Validity and Reliability of Instruments}

Validity of an instrument is how an instrument fulfils the function it is supposed to perform, (Kerlinger, 2003). If the data collected is a true reflection of the variables, then the inferences based on such data will be accurate and of meaning. The research instrument was presented to three experts in the Department of Educational Management and Foundation to determine content validity with an aim of modifying the instrument to capture information relevant to the objective of the study. Reliability of instruments concerns the degree to which a particular instrument procedure gives similar results over a number of repeated trials.To establish reliability of the instrument, a test-retest pilot study on the instruments was done on seven schools which were left out during the actual study. A reliability coefficient index of 0.8 was accepted, Bowling (2002).According to Orodho (2005b) reliability is the dependability of an instrument or procedure in order to obtain information.

\section{Data Analysis}

The quantitative data on data obtained from closed-ended parts of the questionnaires was analysed using descriptive statistics in form of percentages,mean and frequency distribution.It was presented in tables and graphs. The qualitative data obtained from open-ended parts of the questionnaires was analysed on an on-going basis as themes and sub-themes emerged.The interview schedule was analysed using document analysis.

\section{RESULTS AND DISCUSSION}

\section{Enrolment in secondary schools between 2013 - 2017}

The researcher sought to establish school enrolment for both girls and boys between 2013 and 2017; the results are shown in Table 1 
Table 1: Students Enrolment Between 2013 and 2017

\begin{tabular}{llccccc}
\hline Year & Sex & 2013 & 2014 & 2015 & 2016 & 2017 \\
\hline Form 1 & Boys & 846 & 1,128 & 1,034 & 1,175 & 1,316 \\
& Girls & 940 & 1,081 & 1,316 & 1,410 & 1,504 \\
Form 2 & Boys & 987 & 893 & 1,084 & 1,128 & 1,213 \\
& Girls & 995 & 1,034 & 1,153 & 1,363 & 1,418 \\
Form 3 & Boys & 885 & 942 & 978 & 1,024 & 1,127 \\
& Girls & 872 & 934 & 952 & 998 & 1,009 \\
Form 4 & Boys & 823 & 853 & 924 & 982 & 1,269 \\
& Girls & 796 & 813 & 887 & 907 & 973 \\
Total boys & & $\mathbf{3 , 5 4 1}$ & $\mathbf{3 , 8 1 6}$ & $\mathbf{4 , 0 2 0}$ & $\mathbf{4 , 3 0 9}$ & $\mathbf{4 , 9 2 5}$ \\
Total girls & $\mathbf{3 , 6 0 3}$ & $\mathbf{3 , 8 6 2}$ & $\mathbf{4 , 3 0 8}$ & $\mathbf{4 , 6 7 8}$ & $\mathbf{4 , 9 0 4}$ \\
\hline Total & $\mathbf{7 , 1 4 4}$ & $\mathbf{7 , 6 7 8}$ & $\mathbf{8 , 3 2 8}$ & $\mathbf{8 , 9 8 7}$ & $\mathbf{9 , 8 2 9}$ \\
\hline \multicolumn{7}{c}{ Source: Field data $\mathbf{2 0 1 7}$} \\
\end{tabular}

Table 1 shows the students' enrolment between 2013 and 2017 for the school sampled in the study, it shows a steady increase in enrollment from the year 2013. The percentage increase was highest between 2016 and 2017, with an increase of 9.4\%, this could be attributed to the SCEBF that supported the needy students to secondary school. The table also indicates that the number of girls is higher than boys in form one and two while lower in form three and four. This shows that many girls drop out of schools compared to boys.The finding concurs with a study by Mochari (2005) on bursary contribution on girl child in Nyamira District who noted that award and distribution to certain extent benefited few and was gender bias.

The principals were asked to indicate whether SCEBF had increased access to secondary education for children from poor socio-economic background. All principals (100 percent) indicated that SCEBF significantly increased access to education for children from poor socioeconomic background as the funds catered for part of their school fees. This is can be seen in Table 1 as the number of students enrolled between 2013 and 2017 has been increasing. NJeru and Orodho(2003) argued that bursary scheme was meant to promote access and quality in the acqusition of secondary school education.

\section{Students' responses on being sent home for fees}

The researcher sought to determine whether the students have ever been sent home because of school fees. Their responses are shown in Table 2

Table 2: Students' responses on being sent home for fees

\begin{tabular}{lcc}
\hline & Frequency $(\mathrm{F})$ & Percent $(\%)$ \\
\hline Yes & 273 & 68.6 \\
No & 125 & 31.4 \\
\hline Total & $\mathbf{3 9 8}$ & $\mathbf{1 0 0}$ \\
\hline
\end{tabular}

\section{Source: Field Data}

Table 2 indicates that majority of students (68.6 percent) have been sent home because of nonpayment of school fees.This depicts that access and retention of students to secondary schools was significantly affected by lack of finances as reflected by high rate of students being sent home. According to Lewin (2002) in many countries fees and private cost often make it impossible in the absence of affectively targeted financial support for the few poor children that complete primary education to enroll and complete secondary school further skewing participation towards wealthy households. According to UNICEF (2016), people living below 
the poverty line in Kenya stand at 46 percent and this pose affordability problems towards the financing of secondary education. Thus, majority of the families require external financial support to afford the financing of secondary education of their children.

\section{Students Responses on Applying for SCEBF}

The researcher also sought to establish if students have been applying for SCEBF every year. Their responses are shown in Table 4.

Table 4: Students Responses on Applying for SCEBF

\begin{tabular}{lcc}
\hline & Frequency $(\mathrm{F})$ & Percent $(\%)$ \\
\hline Yes & 237 & 59.5 \\
No & 161 & 40.5 \\
\hline Total & $\mathbf{3 9 8}$ & $\mathbf{1 0 0}$ \\
\hline
\end{tabular}

\section{Source: Field Data}

The findings on Table 4 indicate that majority of students (59.5 percent) have been applying for SCEBF every year. This shows that there are a large number of needy students. However, 40.5 percent of students have not been applying every year as some gave up after missing the previous years and lack of information about SCEBF. The findings are in line with Orodho and Njeru (2003) who attested that the deserving beneficiaries did not fully participate in applying for the bursary owing to lack of adequate information about it.

\section{Number of SCEBF Recipient Drop Outs Between 2013 and 2017}

The researcher sought to establish from principals the number of SCEBF recipients who dropped out of school because they could not raise the remaining fees. Their responses are shown in Table 5.

Table 5: Number of SCEBF recipient drop outs between 2013 and 2017

\begin{tabular}{llll}
\hline Years & Boys & Girls & Total \\
\hline 2013 & 11 & 13 & 24 \\
2014 & 9 & 17 & 26 \\
2015 & 5 & 12 & 17 \\
2016 & - & 7 & 7 \\
Total & $\mathbf{2 5}$ & $\mathbf{4 9}$ & $\mathbf{7 4}$ \\
\hline
\end{tabular}

Table 5 indicates that 25 boys and 49 girls who had previously received SCEBF dropped out of school because they could not raise the remaining fees on their own. The number of students dropping out has been decreasing between the year 2014 and 2017. This shows that SCEBF has catered for education needs for many needy students thereby reducing number of drop outs. In addition to these findings, the study endeavored to establish the influence of SCEBF allocation on access to secondary school education. Access to secondary was regressed against SCEBF allocation and the results for standardized beta coefficients presented as shown in Table 6:

Table 6: Effect of SCEBF allocation on access to secondary school education

\begin{tabular}{|c|c|c|c|c|c|c|}
\hline \multirow{2}{*}{\multicolumn{2}{|c|}{ Model }} & \multicolumn{2}{|c|}{$\begin{array}{l}\text { Unstandardized } \\
\text { Coefficients }\end{array}$} & \multirow{2}{*}{$\begin{array}{c}\text { Standardized } \\
\text { Coefficients } \\
\text { Beta } \\
\end{array}$} & \multirow[t]{2}{*}{$\mathbf{t}$} & \multirow[t]{2}{*}{ Sig. } \\
\hline & & B & Std. Error & & & \\
\hline \multirow{2}{*}{1} & (Constant) & 1.040 & .192 & & 5.406 & .000 \\
\hline & Accountability & .697 & .053 & .564 & 13.265 & .000 \\
\hline
\end{tabular}


From the findings presented in Table 6 it is clear that there would be a change in access to secondary education by a value of 1.040 (constant value), without introducing any independent variable in the model. However, based on the selected variables, the findings indicates that SCEBF allocation had unique significant contribution to access to secondary education $(\beta=.564, p=.000)$. These findings imply that whenever a positive change occurs in SCEBF allocation, there are significant improvements in access to secondary school education in the county. These findings were significant as indicated by a $t$ value $t(380)=13.265, p=.000$ implying that these finding did not occur by chance. The findings on the effect of SCEBF allocation were also expressed in terms of the percentage change on access to secondary education. The findings are presented as shown in Table 7.

Table 7: Summary Model on Effect of SCEBF allocation on Access to secondary education

\begin{tabular}{lccccccccc}
\hline Model & $\mathbf{R}$ & $\begin{array}{c}\text { R } \\
\text { Square }\end{array}$ & $\begin{array}{c}\text { Adjusted } \\
\text { R Square }\end{array}$ & $\begin{array}{c}\text { Std. Error of } \\
\text { the Estimate }\end{array}$ & $\begin{array}{c}\text { R Square } \\
\text { Change }\end{array}$ & F Change & df1 & df2 & Sig. F \\
Change
\end{tabular}

The findings in Table 7 show that there is a positive relationship between the independent variable (SCEBF allocation) and access to secondary education as indicated by R value of 0.564 in the overall model. This means that the two variables are associated. The findings further shows an $\mathrm{R}$ square value of 0.318 , which is the proportion of variance in access to secondary school education accounted for by SCEBF allocation. This value can as well be expressed as a percentage when multiplied by $100 \%$ so that a value of $31.8 \%$ becomes the overall percentage change in access to secondary education accounted for by SCEBF allocation. An F value of 175.951 confirms that the findings are not by chance but as a result of fitting the model and therefore the model is significant, $F(1,378)=175.951, p=.000$. These findings imply that overally, SCEBF allocation significantly accounts for $31.8 \%$ change in access to secondary school education. Thus it can be concluded that SCEBF allocation has an effect on secondary school education access as is the case also on equity in financing.

\section{CONCLUSION}

Access rate in secondary school educationafter the establishment of SCEBF increased as many students enrolled especially those from poor socio-economic background as the funds catered for part of their school fees,the enrollment was steady since the inception of this bursary scheme in the year 2013 with the highest increase of 9.4\% between 2016-2017. The number of drop outs who received SCEBF decreased although the number of girls dropping out was more that that for boys.

\section{RECOMMENDATION}

Several recommendations are made to enhance access to education in the sub - county

1. The government should look for innovative ways to enhance access to education

2. Participation should be enhanced by for example making secondary education affordable for majority of the population through lowering all manner fees charged at this level.

3. Creating an enabling environment for private investors in secondary school education 


\section{ABOUT THE AUTHORS}

1. Dickens Oketch. The corresponding author. Is a researcher at the department of education management and foundation where she pursuing her masters degree in education administration, maseno university and Currently employed by teacher service commission as headteacher, Gwasi girls high school in Suba Sub - County, Kenya

2. Dr. James Ochieng Sika. Lecturer, Planning and Economics of Education, Department of Education Management and Foundation, Maseno University. Previously worked with ministry of education as quality assurance and standards officer and with teacher service commission.

3. Dr. JULIUS GOGO. Lecturer, Planning and Economics of Education, Department of Education Management and Foundation, Maseno University. Previously worked with Pwani University, Daystar University and with teacher service commission.

\section{References}

Ayiga, N. (1991). Causes of Low Enrolment and High Dropout Rates in Primary Education in Uganda. Abridged Research Report.

Ayot,N,\& Briggs,H.(1992).Economics of Education.Nairobi:E.A.P

Baumol J W, Blinder SA (1979). Economics, Principles and Policy. NewYork: Harcourt Brace Jovanovich, Inc.

Cohen,L \& Manion,L.(1992).Research methods in education.London:Rutledge.

Gay,L. (1996): Educational Research, Competences for Analysis and ApplicationCharles E. Merril Publishing Company.

Government of Uganda, (2010).Appraisal report: Updated Education Sector Strategic Plan, 2010-2015. Kampala.Gorvenment printer.

Kiage,J.M.(2003).Effects of cost-sharing policy on secondary school enrolment in Nyamira District.Unpublished Thesis.Maseno University.

Lewin, K. M. (2003). Investigating the missing link:The case for expanded secondary s schooling in Sub-Saharan Africa. Association for the Development of Education in Africa (ADEA). Biennial: Mauritius

Maeke, E. (2009). School Shake up: Case Study of Moi Girls Marsabit. www.changemakers.com. Retrieved on 17.12.2009

Mellen M. O. (2004). The role of Government bursary fund in enhancing the participation of girls in secondary education in Nyamira District, Kenya; Unpublished M.Ed Thesis, Kenyatta University.

MoEST, (2015). New Fee Guidelines For Secondary School. Government Printers

Mirigat (2003) Facilitating secondary education, Kenyan Scenario: a case of Government Bursary Fund.

Mugenda, O. M.Mugenda, A. G. (2007) Qualitative and Quantitative approaches. Nairobi. Acts press.

Ngware M, Onsomu, E. N ,Muthaka D \& Kosimbei, G (2006). Financing of Secondary Education in Kenya: Costs and Options. Institute for Public Policy Research and Analysis -Discuss Paper No. 55 Nairobi.

Njeru E.HC and Orodho A (2003) Secondary School Bursary Scheme Implementation and Challenges. IPAR Discussion Paper Series No. 036/2003.

Njeru,E.and Orodho,J.A(2003).Access and participation in secondary school Education in Kenya:Emerging issues and policy implications,IPAR DP 037/2003,Nairobi;Regal Press Kenya Ltd.

Nyakeri, B. (2011). Analysis of the Effects of Subsidized Secondary School Education on Access and Participation: A case study of Manga District, Nyamira County. Unpublished Research Project, Kenyatta University.

Orodho,J.A.(2005a).Technique of writing Research Proposal and Report to Education \& Social Sciences(2nd ed).Nairobi:Kaneza H.P.enterprises.

Psacharopoulos,G.\& Woodhall, M(1985) Education for Development.An analysis of investment choices.Washington.D.C.Oxford University Press.

Siaya County Social Audit Report-2014. 
Oketch, D., Sika, J. O., \& Gogo, J. O. (2019). County Education Bursary Fund Influence On Access To Secondary Education In Siaya County, Kenya. Advances in Social Sciences Research Journal, 6(3) 401-412.

Todaro,P.M.,\& Smith,C.S. (2006)Economic Development.9th edition.England:Pearson Education LTD.

Veepoor. A. (2007). At the crossroads choices for Secondary Education and Training from www.iiep.UNESCO.org.on 14th January 2009.

World Bank (2007): World Development Report available at www.worldbank.org/external/def 